\title{
Aeromonas Infections in African Sharptooth Catfish
}

\section{Walaa FA Emeish ${ }^{1}$, Hams MA Mohamed ${ }^{2}$ and Ahmad A Elkamel ${ }^{3 *}$}

${ }^{1}$ Faculty of Veterinary Medicine, Department of Fish Diseases, South Valley University, Qena, Egypt

${ }^{2}$ Faculty of Veterinary Medicine, Department of Microbiology, South Valley University, Qena, Egypt

${ }^{3}$ Faculty of Veterinary Medicine, Department of Aquatic Animals Medicine and Management, Assiut University, Assiut, Egypt

\begin{abstract}
The aim of this study was to investigate the dominant species of Aeromonas in naturally infected African Sharptooth catfish, Clarias gariepinus, in Qena, Egypt and the distribution of two virulence genes among the isolates to assess their pathogenicity. Twenty-five isolates of Aeromonas were recovered from infected fish showing signs of septicemia. Restriction-fragment-length-polymorphism (RFLP) analysis of the 16S-rDNA amplified products demonstrated that the specie isolated were Aeromonas hydrophila (56\%) and Aeromonas veronii (44\%). Isolates were screened for the cytotoxic enterotoxin, act, and aerolysin, aerA, genes. The act gene was detected only in A. hydrophila, while the aerA gene was more frequently found among all isolates. Catfish challenged with an $A$. hydrophila isolate that have both the act and aerA genes showed higher mortalities $(80.9 \%)$ and more severe signs of septicemia than those challenged with an isolate that lacks both genes studied.
\end{abstract}

Keywords: Aeromonas; Clarias gariepinus; act gene; aerA gene; RFLP analysis

\section{Introduction}

Several cases of septicemia in African Sharptooth catfish, Clarias gariepinus, have been submitted to our lab by the local fishermen in Qena, Egypt, who reported that such case, have recently increased in the small tributaries of the River Nile. Although there is no official data for the rates of infections and mortalities, our preliminary investigations indicated that main cause of such infections is Aeromonas. Genus Aeromonas causes serious problems in various fish and shellfish species that is characterized by septicemia and resulting in mass mortalities and high economic losses [1,2]. Out of the 24 reported species within the genus [3], only Aeromonas hydrophila, Aeromonas veronii, Aeromonas caviae, and Aeromonas jandaei are considered the main species that infect fish [4,5] causing Motile Aeromonas Septicemia (MAS).

There are many extracellular virulence proteins that contribute to the pathogenicity of Aeromonas spp. [6], including exotoxins such as haemolysins, cytotonic and cytotoxic enterotoxin $[7,8]$ and aerolysin [9]. The cytotoxic enterotoxin $(a c t)$ is aerolysin related with approximately $90 \%$ homology [10]. The act gene is a major virulence factor of Aeromonas that can create pores in the erythrocyte membranes, [11]. It possesses hemolytic, cytotoxic, and enterotoxic activities [12]. Aerolysin gene (aerA) is recorded to be the commonly regarded virulence gene produced by some strains of Aeromonas, so its detection proposed to be a reliable approach to investigate pathogenic Aeromonas strain. It is an extracellular, soluble, hydrophilic protein exhibiting both haemolytic and cytolytic properties $[13,14]$ by pore formation, as it binds to eukaryotic cells and aggregates to creates unadjusted pores in the membrane of targeted cells leading to the destruction of the membrane permeability and lysis [15].

The precise and accurate identification and characterization of a pathogen, together with the detection of the prospect virulence traits are the corner stone for epidemiological investigations and accordingly designing the control programs and preventive measures. The current study aimed to investigate the species distribution of Aeromonas isolates among naturally infected African Sharptooth catfish in Qena, Egypt. The distribution of two extracellular virulence genes among the isolates was investigated as a means of assessing the pathogenicity to catfish based on the genetic profile. Additionally, a challenge study was conducted to further define the correlation between the genetic profiles of the isolates and their pathogenicity.

\section{Materials and Methods}

All experiments were done according to the recommendations listed in the care and use of fish in research, teaching and testing section in the guide to the care and use of experimental animals, Canadian Council on Animal Care (CCAC), Ottawa, Ontario, Canada [16].

\section{Clinical examination and bacterial isolation}

Fifty African Sharptooth catfish with average weight of 100 to $150 \mathrm{~g}$ and total length of 23 to $27 \mathrm{~cm}$ showing signs of septicemia were submitted by the local fishermen to the Aquatic Diagnostic Laboratory, Faculty of Veterinary Medicine, South Valley University. Fish were caught from small tributaries of the River Nile at Qena Governorate, Egypt. Inoculations from the kidneys and spleen were made on tryptic soya broth, TSB (Oxoid, England), and incubated at $28^{\circ} \mathrm{C}$ for 24 hours. Then, the broth cultures were streaked on Aeromonas selective agar-base, ASA (Biolife, Italy) and incubated at $28^{\circ} \mathrm{C}$ for 24 hours, where green colonies with dark centers were presumptively considered to be Aeromonas [17].

\section{Conventional identification of the suspected isolates}

Conventional phenotypic identification was conducted according to Austin et al. [18] based on the morphological, biochemical and metabolic characters. It included Gram stain, oxidase, catalase, indole (Kovac's method), voges-proskauer, methyl red, $\mathrm{H}_{2} \mathrm{~S}$ production, esculin hydrolysis, acid and gas production from glucose, motility using semisolid agar, growth on 6 and $10 \%$ sodium chloride, and resistance to $150 \mathrm{~g} / \mathrm{ml}$ of vibriostatic agent $0 / 129$ (Oxoid).

*Corresponding author: Elkamel AA, Faculty of Veterinary Medicine, Department of Aquatic Animals Medicine and Management, Assiut University, Assiut, Egypt, Tel: +2 01222303195; Fax: +2 (088) 2080501; E-mail: aelkamel@aun.edu.eg

Received September 01, 2018; Accepted September 24, 2018; Published September 27, 2018

Citation: Emeish WFA, Mohamed HMA, Elkamel AA (2018) Aeromonas Infections in African Sharptooth Catfish. J Aquac Res Development 9: 548. doi: 10.4172/21559546.1000548

Copyright: $\odot 2018$ Emeish WFA, et al. This is an open-access article distributed under the terms of the Creative Commons Attribution License, which permits unrestricted use, distribution, and reproduction in any medium, provided the original author and source are credited. 
Citation: Emeish WFA, Mohamed HMA, Elkamel AA (2018) Aeromonas Infections in African Sharptooth Catfish. J Aquac Res Development 9: 548. doi: 10.4172/21559546.1000548

\section{Molecular identification of the suspected isolates to the genus} level

Bacterial DNA was extracted from the suspected isolates using the Gene JET genomic DNA purification kit (Thermo Scientific, EU) according to the manufacturer recommendations and then kept at $-20^{\circ} \mathrm{C}$ until the time of use Polymerase chain reactions (PCR) were conducted to amplify a gyrB-gene target of approximately 1100 base pair (bp) using Aeromonas-specific primers [19]. Amplicons were analysed using $1.5 \%$ agarose gel electrophoresis in Tris-acetate EDTA (TAE) buffer, stained with ethidium bromide $(50 \mu \mathrm{l} / \mathrm{L})$ and visualized on UV transilluminator system (MultiDoc- It, UVP, UK).

\section{Molecular identification of the suspected isolates at the spe-} cies level

Polymerase chain reactions were conducted to amplify a hypervariable segment of the Aeromonas 16S-rDNA of about 1500 bp using genus-specific primers as per Borrell et al. [20]. Amplicons were subjected to restriction-fragment-length-polymorphism (RFLP) analysis with BstSNI and MboI restriction enzymes (Invitrogen, USA) as per Ghatak et al. [21], and the digestion products were analysed using $1.5 \%$ agarose gel electrophoresis as previously described.

\section{Detection of virulence genes in the Aeromonas isolates}

To investigate the distribution of two virulence genes, act and aerA, among the Aeromonas isolates, a PCR study was conducted using the primers listed in Table 1 and the protocol described by Hu et al. [22]. Amplicons were analysed using $1.5 \%$ agarose gel electrophoresis as previously described.

\section{Pathogenicity of the A. hydrophila isolated to catfish}

African Sharptooth catfish with average body weight of $100 \pm 5$ $\mathrm{g}$ and total length $25 \pm 3 \mathrm{~cm}$ were obtained from a private fish farm with no history of Aeromonas septicemia and were acclimated for 2 weeks in fiber glass aquaria supplied with dechlorinated tap water and aeration, at the wet laboratory, Department of Fish Diseases, Faculty of Veterinary Medicine, South Valley University. Two strains, one strain with $a c t^{+}$aerA $A^{+}$and another one with act aer $A^{-}$genotypes were used in experimental infection of catfish. Acclimated catfish were divided into 4 groups with 7 fish each in a completely randomized design. The first group was intra-peritoneally $(\mathrm{I} / \mathrm{P})$ injected with $0.5 \mathrm{ml}$ of $6 \times 10^{6} \mathrm{cfu} /$ $\mathrm{ml}$ of $a c t^{+} a e r A^{+} A$. hydrophila. The second group was I/P injected with actaer $A^{-}$A. hydrophila with the same dose as above. The third group was $\mathrm{I} / \mathrm{P}$ injected with $0.5 \mathrm{ml}$ of sterile saline (sham control), and the fourth group was un-injected as a negative control. The entire study was done in three replicates where clinical signs, post mortem lesions, and mortalities were recorded daily for up to two weeks. Moribund catfish were bacteriologically examined to re-isolate the causative Aeromonas strain from the internal organs. Identification of re-isolated bacteria was conducted by the molecular approaches as described above.

\section{Results}

\section{Clinical examination and bacterial isolation}

Collected catfish showed the signs of bacterial septicemia that included exophthalmia, skin ulceration, abdominal distension, scattered haemorrhages on the body surface and muscles, congestion of the fins, and fin rot. Internally, there were accumulations of yellowish or bloody ascetic fluids with friable, congested and enlarged organs.

\section{Conventional identification of the suspected isolates}

Bacteriological examination of the catfish resulted in recovery of 25 isolates were suspected to be Aeromonas based on their morphology on the ASA. Based on the conventional phenotypic, morphologic and biochemical characterization of the isolates, all the 25 isolates were presumptively identified as Aeromonas, although they showed variable results for esculin hydrolysis and gas and $\mathrm{H}_{2} \mathrm{~S}$ production on TSI (Data not shown).

\section{Molecular identification of the suspected isolates}

Using the $g y r B$ primers resulted in amplification of targets of all the 25 isolates giving amplicons of $1100 \mathrm{bp}$ as shown in Figure 1. In addition, 16S-rDNA targets of the isolates were amplified and used for RFLP analysis. Restriction digestions of the 16S-rDNA amplicons with BstSNI resulted in two patterns of digestions, where only 14 (56\%) amplicons were digested giving two fragments of 1104 and 462 bp length as shown in Figure 2 and their corresponding isolates were identified as A. hydrophila, while the other 11 (44\%) amplicons remained uncut. Digesting these remaining 11 amplicons with $\mathrm{MboI}$ resulted in five fragments of about $618,445,219,160 \mathrm{bp}$, and a smaller fragment of less than a $100 \mathrm{bp}$ in length as shown in Figure 3 and their corresponding isolates were identified as $A$. veronii.

\section{Detection of virulence genes in the Aeromonas isolates}

Primers targeting the cytotoxic enterotoxin (act) and aerolysin (aerA) genes resulted in amplicons of $232 \mathrm{bp}$ and $301 \mathrm{bp}$ respectively, (Figures 4 and 5), and revealed that the act gene was found only in $A$. hydrophila with rate of $2 / 14(14.3 \%)$ isolates (Table 2) while aerolysin (aerA) gene was present in 17/25 (68\%) isolates, out of which 9 isolates

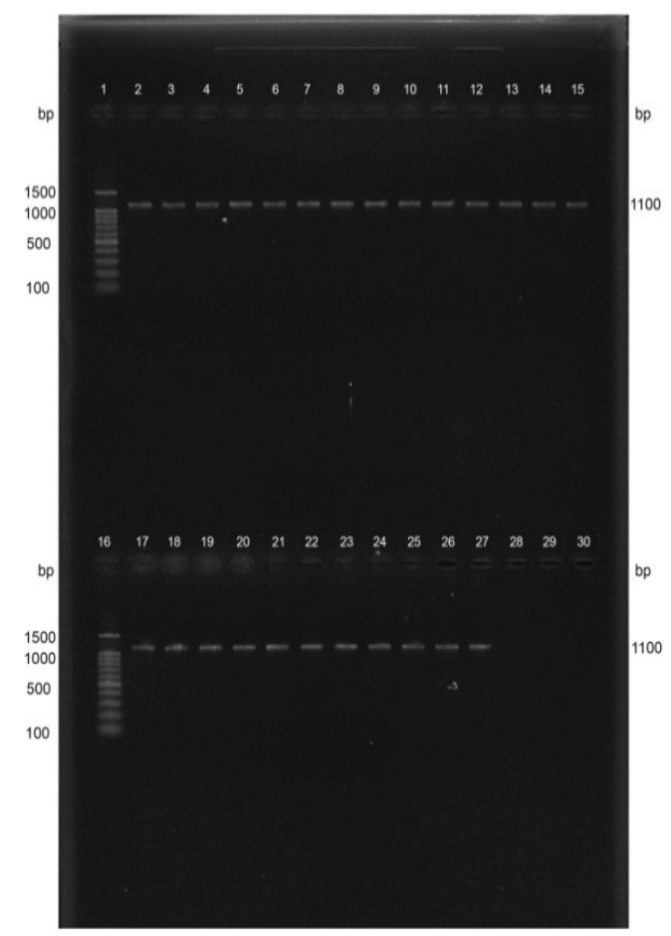

Figure 1: Amplifying a $1100 \mathrm{bp}$ fragment of gyrB-gene of clinical isolates of Aeromonas using Aeromonas-specific primers. Lane 1 and 16: 100 bp ladder, Lane 2-15 and 17- 27: Clinical isolates of the present study, Lane 29: Negative control (No DNA). 
Citation: Emeish WFA, Mohamed HMA, Elkamel AA (2018) Aeromonas Infections in African Sharptooth Catfish. J Aquac Res Development 9: 548. doi: 10.4172/21559546.1000548

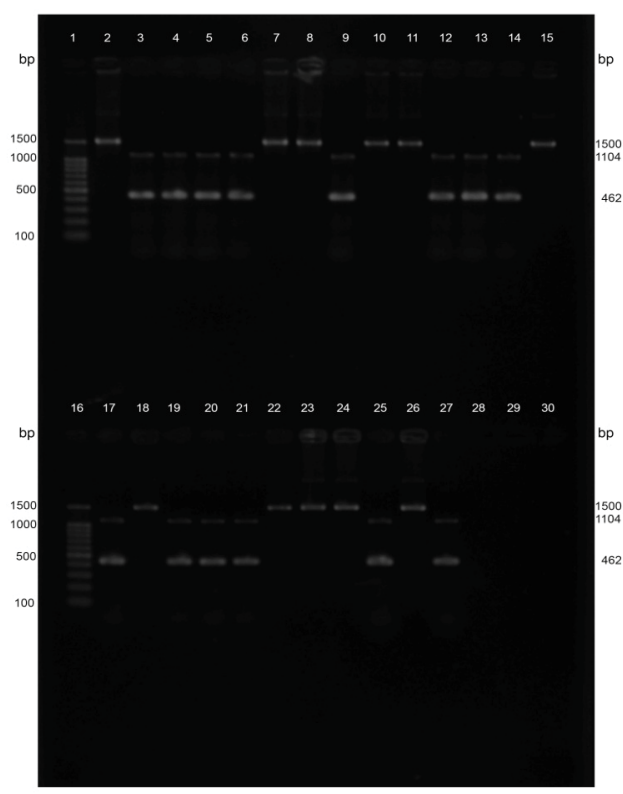

Figure 2: Restriction digestion of 25 Aeromonas spp. 16S-rDNA amplicons (1500 bp) with BstSNI restriction enzyme. Lane 1 and 16: $100 \mathrm{bp}$ ladder, Lanes 3-6, 9, 12-14,17, 19-21, 25, and 27: Digested Aeromonas hydrophila showing two fragments of 1104 and 462 bp length. Other Aeromonas spp. amplicons (1500 bp) were uncut (Lanes 2, 7, 8, 10, 11, 15, 18, 22-24 and 26).

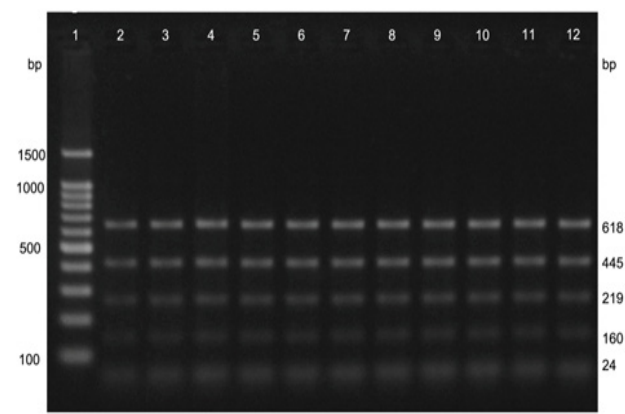

Figure 3: Restriction digestion of Aeromonas veronii 16S-rDNA amplicons (1500 bp) with $\mathrm{Mbol}$ restriction enzyme. Lane 1: 100 bp ladder; lanes 2-12: Digested $A$. veronii showing $618,445,219,160$ and less than $100 \mathrm{bp}$ fragments.

were A. hydrophila with rate of 9/14 (64.3\%), (Table 2). Based on the distribution of the two genes, the 25 isolates were classified into four genotypic groups as act ${ }^{+}$aerA $A^{+}(2 / 25,8 \%)$, act aerA $^{-}(0 / 25,0 \%)$, act $\operatorname{aerA}^{+}(15 / 25,60 \%)$, and act aerA $(8 / 25,32 \%)$.

\section{Pathogenicity of the A. hydrophila isolated to catfish}

The A. hydrophila isolate with the $a c t^{+} a e r A^{+}$genotype caused $80.9 \%$ average mortalities of the fish challenged. The clinical signs and post-mortem findings seen on fish challenged included scattered hemorrhages allover different parts of the body, sloughing and congestion of the caudal fin, and hemorrhages and deep skin ulcers at the caudal peduncle, and severe abdominal distention. Post mortem examination revealed the presence of severe inflammatory response with hemorrhages in the abdominal cavity, hemorrhages and congestions in ovaries, liver, kidney and spleen, while other fish showed pale coloration of the liver. Challenging the catfish with the same dose

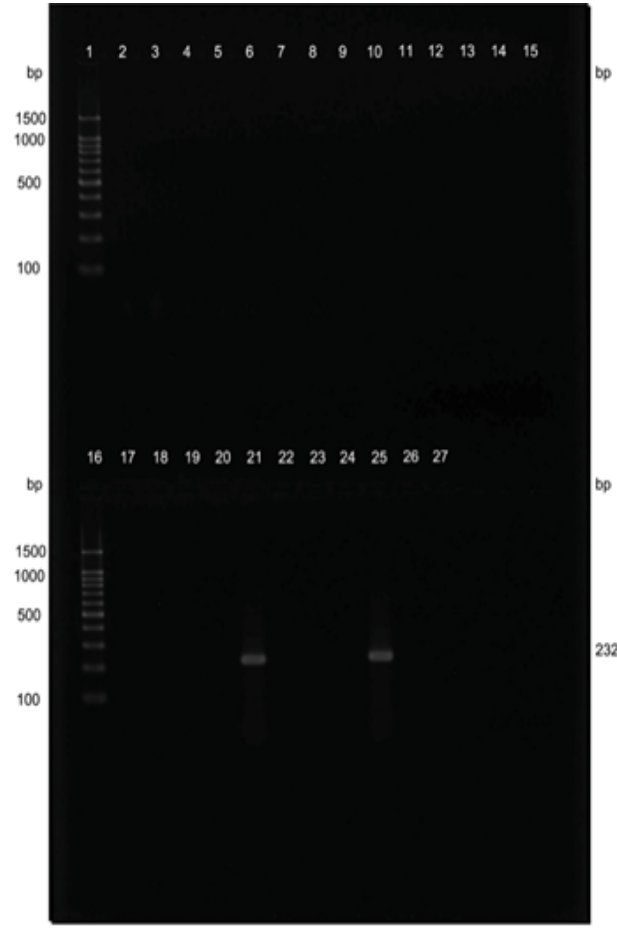

Figure 4: Detection of enterotoxin (act) gene in 25 Aeromonas spp. isolates showing a $232 \mathrm{bp}$ amplicons in positive strains (Lanes 21 and 25). Lanes 1 and 16 are $100 \mathrm{bp}$ ladder.

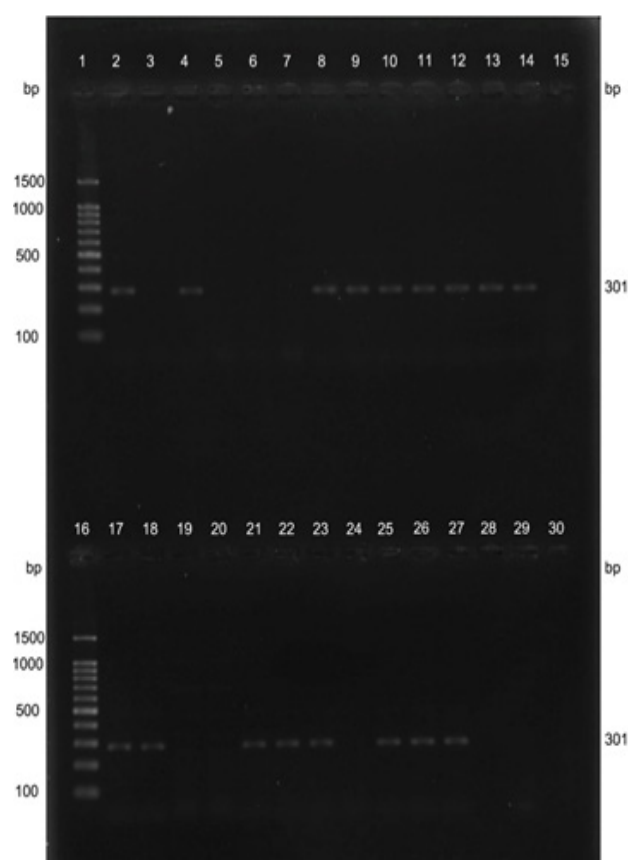

Figure 5: Detection of aerolysin (aerA) gene in 25 Aeromonas spp. isolates showing a $301 \mathrm{bp}$ amplicons in positive strains (Lanes 2, 4, 8-14, 17, 18, 21-23 and 25-27). Lanes 1 and 16 are 100 bp ladder.

of the other A. hydrophila isolate (act aer $A^{-}$genotype) resulted in only $54 \%$ average mortalities where the clinical signs and lesions seen were less severe than those observed with the other isolate $\left(a c t^{+} a e r A^{+}\right)$. 
Citation: Emeish WFA, Mohamed HMA, Elkamel AA (2018) Aeromonas Infections in African Sharptooth Catfish. J Aquac Res Development 9: 548. doi: 10.4172/21559546.1000548

\begin{tabular}{|c|c|c|c|}
\hline $\begin{array}{l}\text { Target } \\
\text { genes }\end{array}$ & Primer sequence & $\begin{array}{l}\text { Product } \\
\text { sizes/bp }\end{array}$ & Reference \\
\hline \multirow{2}{*}{ gyrB } & F 5' TCCGGCGGTCTGCACGGCGT 3' & \multirow{2}{*}{1100} & \multirow{2}{*}{ [19] } \\
\hline & R 5’ TTGTCCGGGTTGTACTCGTC 3' & & \\
\hline \multirow{2}{*}{ 16S-rDNA } & F 5' AGAGTTTGATCATGGCTCA 3' & \multirow{2}{*}{1502} & \multirow{2}{*}{ [20] } \\
\hline & R 5' GGTTACCTTGTTACGACTT 3' & & \\
\hline \multirow{2}{*}{ act gene } & F 5' GAGAAGGTGACCACCAAGAAC 3' & \multirow[t]{2}{*}{232} & \multirow{2}{*}{ [22] } \\
\hline & R 5' AACTGACATCGGCCTTGAACTC 3' & & \\
\hline \multirow{2}{*}{ aerA gene } & F 5' AACCGAACTCTCCAT 3' & \multirow{2}{*}{301} & \multirow{2}{*}{ [22] } \\
\hline & R 5' TTGTCCGGGTTGTACTCGTC 3' & & \\
\hline
\end{tabular}

Table 1: Primers used in the current study.

\begin{tabular}{|c|c|c|c|}
\hline Genes & $\begin{array}{c}\text { A. hydrophila } \\
(\mathbf{n = 1 4 )}\end{array}$ & A. veronii $(\mathbf{n = 1 1 )}$ & Total $(\mathbf{n = 2 5 )}$ \\
\hline act gene & $2(14.3 \%)$ & $0(0 \%)$ & $2(8 \%)$ \\
\hline aerA gene & $9(64.3 \%)$ & $8(72.7 \%)$ & $17(68 \%)$ \\
\hline
\end{tabular}

Table 2: The distribution of act and aerA virulence genes in Aeromonas hydrophila and Aeromonas veronii isolates.

\section{Discussion}

The distribution of Aeromonas isolates among infected African Sharptooth catfish was studied and their pathogenicity to catfish based on the genetic profile was assessed to investigate natural infection incidences reported with losses in the catfish in small tributaries of the River Nile at Qena governorate, Egypt. Fish pathogenic aeromonads are ubiquitous inhabitants of the aquatic ecosystems [23] making their interactions with fish uncontrolled [24]. Motile aeromonads are not uncommon in wild fishes. It was reported that gizzard shad (Dorosoma cepedianum) of Potomac River (Maryland, USA) had motile Aeromonas septicemia because of spawning stress [25]. Also, Paniagua et al. [26], were able to recover Aeromonas isolates from the River Porma, Leon, Spain that were identified as A. hydrophila, A. sobria and A. caviae.

To investigate the dominant pathogenic Aeromonas spp. in Sharptooth catfish in this study, accurate and definitive identification of the isolates is essential. Correct identification of the pathogen is crucial for the epidemiological studies, tracing-back disease outbreaks, and designing the appropriate control programs and treatment. In the present study a combination of conventional morphologic and metabolic characters was used to presumptively identify 25 isolates as Aeromonas spp. but was not conclusive in identifying the isolates to the species level. The genus identity of the isolates was, however, confirmed by amplifying the housekeeping gene, gyrB, using Aeromonas-specific primers [19]. All the 25 isolates were accurately identified to the species level as $A$. hydrophila and $A$. veronii by RFLP of the 16S-rDNA gene using a combination of two restriction enzymes. RFLP has been shown to be suitable for routine laboratory practices giving more easily recognizable DNA-band patterns to differentially identify the clinically important Aeromonas to the species level $[20,27]$. The minor deviations observed in the sizes of the digested fragments in case of $A$. veronii from those reported by Ghatak et al. [21] may be due to strain differences of the bacteria isolated in the present study from those previously investigated [21].

Aeromonas hydrophila and A. veronii were not only the dominant, but in fact the only aeromonads isolated from catfish in the present study. A. hydrophila is one of the predominant aeromonads in fish [28] and has been associated with great fish mortalities around the world [3]. Also, previous studies showed that $A$. hydrophila and A. veronii were the most prevalent aeromonad species found in fish and water $[4,24]$. In another study, A. veronii was the most common species isolated from fish and water environment, while $A$. hydrophila isolates were significantly more frequent in diseased fish than in healthy ones [22]. On the other hand, A. sobria was the dominant Aeromonas isolated from diseased fish in Spain [29].

The pathogenicity of Aeromonas spp. can be evaluated using the virulence determinants as genetic indicators [30]. In the present study, PCR assays have been used for the detection of two major Aeromonas virulence determinants (act and aerA) to assess the pathogenicity of the isolates. The cytotoxic enterotoxin gene, act, is one of the primary genes that makes Aeromonas pathogenic [31]. Also, the presence of hemolytic gene aerolysin, aerA, is an irrefutable indication of virulence in pathogenic A. hydrophila [32,33].

In this study, 25 Aeromonas isolates were classified into four genetic groups by defining their respective act and aer $A$ genes $\left(\right.$ act $^{+}$aer $A^{+}$, act ${ }^{+}$aerA $A^{-}$act aer $A^{+}$, and act aer $\left.A^{-}\right)$. Interestingly, the act gene was detected only in A. hydrophila isolates of the present study and was less frequent (14.3\%) than in other reports where act was the most frequently found enterotoxin gene [34]. Furthermore, 65\% of Aeromonas strains out of 350 clinical and environmental isolates were positive for act/hlyA/aerA [30]. Also, a wide variety in the combinations of virulence factors were reported in the Aeromonas isolates [34]. On the other hand, the distribution of the aerA gene among the Aeromonas isolates of the present study was higher (64.3\%) than that of the act gene. Generally, aerA is widely distributed among Aeromonas isolates $[35,36]$.

Virulence is essentially related to disease and pathology and subsequently should be evaluated in terms of morbidity and mortality of the host, thus in-vivo challenge studies is crucial to investigate pathogenicity [37]. In this study, as A. hydrophila was the dominant Aeromonas isolated, and thus was used in experimental infection of catfish. Challenging catfish with the A. hydrophila strain which has both of virulence genes $\left(a c t^{+} a e r A^{+}\right)$caused higher mortalities and severe clinical signs when compared to those caused by the less virulent strain (act aer $\left.A^{-}\right)$. The act gene has the ability to lyse red blood cells by creating pores in the erythrocyte membranes $[11,38]$. This may explain the external and internal haemorrhages with septicemia seen on catfish challenged in the present study. In addition, the act gene has cytotoxic as well as tissue damage activities which affected the liver, kidneys, and other internal organs in the challenged catfish, herein, making them congested and friable. Furthermore, the ascites noticed in the present study may be due to activation of proinflammatory cytokines by the act [39]. On the other hand, the hemolytic and cytolytic activities of the aerolysin gene [40] found in some strains of A. hydrophila, may explain the bloody ascites and internal tissue damage associated with the challenge of catfish in the present study.

Interestingly, A. hydrophila strain that lacks the two virulence genes (act aer $A^{-}$) produced less mortalities (54\%) and less severe signs than those recorded with the virulent strain $\left(a c t^{+} a e r A^{+}\right)$. Previous studies reported that an act-isogenic mutant was significantly attenuated in a mouse model [39], and the 50\% lethal dose of act mutants in mice was $1.0 \times 10^{8}$, compared to $3.0 \times 10^{5}$ for the wild-type Aeromonas, where reintegration of the wild type act gene in these mutants resulted in complete restoration of the virulence in mice. Similarly, inactivation of the aer $A$ gene resulted in a nine-fold increase in $\mathrm{LD}_{50}$ in the suckling mouse model [40].

Although the act and aerA genes are major virulence determinants of Aeromonas, they are not the only virulence genes reported to contribute to the pathogenicity during infections. This was supported 
Citation: Emeish WFA, Mohamed HMA, Elkamel AA (2018) Aeromonas Infections in African Sharptooth Catfish. J Aquac Res Development 9: 548. doi: 10.4172/21559546.1000548

by the mortalities and signs seen in the present study associated with the strain that lacks both act and aerA genes. Virulence of Aeromonas is complex and not necessarily because of a particular virulence gene but likely requires the interaction of several virulence genes [36]. Synergy between virulence determinants may occur, where the act gene in A. hydrophila is iron regulated [39] that could be unregulated by the action of the aerA gene releasing iron from haemolyzed RBCs.

\section{Conclusion}

The present study clearly shows that $A$. hydrophila is the dominant Aeromonas infecting catfish in Qena, Egypt. A. hydrophila harbor many virulence factors where act and aerA genes play a major role in inducing lesions and diseases in catfish.

\section{Acknowledgment}

We would like to thank the Aquatic Animals Medicine Unit, Assiut University for the direct help and technical assistance with the RFLP study.

\section{References}

1. Azad IS, Rajendran KV, Rajan JS, Vijayan TC, Santiago TC (2001) Virulence and histopathology of Aeromonas hydrophila (SAH. 93) in experimentally infected tilapia, Oreochrornis mossambicus (L.). J Aqua Trop 16(3): 265-275.

2. Noga EJ (2010) Text book of fish disease: Diagnosis and treatment, $2^{\text {nd }}$ ed, Wiley-Blackwell, USA.

3. Janda JM, Abbott SL (2010) The genus Aeromonas: Taxonomy, pathogenicity, and infection. Clin Microbiol Rev. 23: 35-73.

4. Janda JM, Abbott SL (1998) Evolving concepts regarding the genus Aeromonas: An expanding panorama of species, disease presentations, and unanswered questions. Clin Infect Dis 27: 332-344.

5. Joseph SW, Carnahan AM (2000) Update on the genus Aeromonas. ASM News 66: 218-223.

6. Noor El Deen AE, Sohad Dorgham M, Hassan AHM, Hakim AS (2014) Studies on Aeromonas hydrophila in cultured Oreochromis niloticus at Kafr El Sheikh Governorate, Egypt with reference to histopathological alterations in some vital organs. World J Fish Marine Sci 6: 233-240.

7. Chakraborty T, Montenegro MA, Sanyal SC, Helmuth R, Bulling E, et al. (1984) Cloning of enterotoxin gene from Aeromonas hydrophila provides conclusive evidence of production of a cytotoxic enterotoxin. Infect Immun 46: 435-441.

8. Howard SP, Macintyre S, Buckley JT (1996) The genus Aeromonas, Austin B Altwegg M, Gosling PJ and Joseph S (eds.). Singapore, John Wiley and Sons pp: 267-286.

9. Daskalov H (2006) The importance of Aeromonas hydrophila in food safety. Food Contr 17: 474-483.

10. Howard SP, Garland WJ, Green MJ, Buckley JT (1987) Nucleotide sequence of the gene for the hole-forming toxin aerolysin of Aeromonas hydrophila. J Bacteriol 169: 2869-2871.

11. Ferguson MR, Xu XJ, Houston CW, Peterson JW, Coppenhaver DH, et al (1997) Hyperproduction, purification, and mechanism of action of the cytotoxic enterotoxin produced by Aeromonas hydrophila. Infect Immun 65: 4299-4308.

12. Rose JM, Houston CW, Kurosky A (1989) Bioactivity and immunological characterization of a cholera toxin-cross-reactive cytolytic enterotoxin from Aeromonas hydrophila. Infect Immun 57: 1170-1176.

13. Rabaan A, Gryllas I, Tomas T, Shaw J (2001) Motility and the polar flagellum are required for Aeromonas caviae adherence to HEp-2 Cells. Infection and Immunity 69: 4257-4267.

14. Yousr AH, Napis S, Rusul GRA, Son R (2007) Detection of aerolysin and hemolysin genes in Aeromonas spp. isolated from environmental and shellfish sources by polymerase chain reaction. Asian Food J 14(2): 115-122.

15. Parker MW, Buckley JT, Postma JP, Tucker AD, Leonard K, et al. (1994) Structure of the Aeromonas toxin proaerolysin in its water-soluble and membrane-channel states. Nature 367: 292-295

16. CCAC (2005) Guidelines on: The care and use of fish in research, teaching and testing, guide to the care and use of experimental animals, Canadian Council on Animal Care (CCAC), Ottawa, Ontario, Canada.
17. Kamble SR, Meshram SU, Shanware AS (2011) PCR detection of aerolysin from Aeromonas $s p$. isolated from diseased and healthy fish. J Environ Res Develop 5: 758-763.

18. Austin B, Austin DA (2016) Aeromonadaceae representatives (Motile Aeromonads). Bacterial fish pathogens. Disease of farmed and wild fish, $6^{\text {th }}$ edition, Springer Nature publishing pp: 161-214.

19. Yanez MA, Catalan V, Apraiz D, Figueras MJ, Martinez-Murcia AJ (2003) Phylogenetic analysis of members of the genus Aeromonas based on gyrB gene sequences. Int J Syst Evol Microbiol 53: 875-883.

20. Borrell N, Acinas SG, Figueras MJ, Murcia AJM (1997) Identification of Aeromonas clinical isolates by restriction fragment length polymorphism of PCR-amplified 16S-rRNA genes. J Clin Microbiol 35: 1671-1674.

21. Ghatak S, Agarwal RK, Bhilegaonkar KN (2007) Species identification of clinically important Aeromonas spp. by restriction fragment length polymorphism of 16S rDNA. Lett Appl Microbiol 44: 550-554.

22. Hu M, Wang N, Pan ZH, Lu CP, Liu YJ (2012) Identity and virulence properties of Aeromonas isolates from diseased fish, healthy controls and water environment in China. Letters in Applied Microbiology 55: 224-233.

23. Monfort P, Baleux B (1990) Dynamics of Aeromonas hydrophila, Aeromonas sobria and Aeromonas caviae in a sewage treatment pond. Appl Environ Microbiol 56: 1999-2006.

24. Ottaviani D, Parlani C, Citterio B, Masini L, Leoni F, et al. (2011) Putative virulence properties of Aeromonas strains isolated from food, environmental and clinical sources in Italy: A comparative study. Int J Food Microbiol 144 538-545.

25. Toranzo AE, Baya AM, Romalde JL, Hetrick FM (1989) Association of Aeromonas sobria with mortalities of adult gizzard shad, Dorosoma cepedianum Lesueur. Journal of Fish Diseases 12: 439-448.

26. Paniagua C, Rivero O, Anguita J, Naharro G (1990) Pathogenicity factors and virulence for rainbow trout (Salmo gairdneri) or motile Aeromonas spp. isolated from a river. J Clin Microbiol 28: 350-355.

27. Figueras MJ, Soler L, Chacon MR, Guarro J, Martinez-Murcia AJ (2000) Extended method for discrimination of Aeromonas spp. by $16 \mathrm{~S}$ rDNA RFLP analysis. Int J Syst Evol Microbiol 50: 2069-2073.

28. Nielsen ME, Hoi L, Schmidt AS, Qian D, Shimada T, et al. (2001) Is Aeromonas hydrophila the dominant motile Aeromonas species that causes disease outbreaks in aquaculture production in the Zhejiang Province of China. Dis Aquat Organ 46: 23-29.

29. Beaz-Hidalgo R, Alperi A, Bujan N, Romalde JL, Figueras MJ (2010) Comparison of phenotypical and genetic identification of Aeromonas strains isolated from diseased fish. Syst Appl Microbiol. 33: 149-153.

30. Kingombe Cl, Huys G, Tonolla M, Albert MJ, Swings J, et al. (1999) PCR detection, characterization, and distribution of virulence genes in Aeromonas spp. Appl Environ Microbiol 65: 5293-5302.

31. Chopra AK, Xu XJ, Ribardo D, Gonzalez M, Kuhl K, et al. (2000) The cytotoxic enterotoxin of Aeromonas hydrophila induces proinflammatory cytokine production and activates arachidonic acid metabolism in macrophages. Infect Immun 68: 2808-2818.

32. Stelma GN, Johnson CH, Spaulding $P$ (1986) Evidence for the direct involvement of P-hemolysin in Aeromonas hydrophila enteropathogenicity. Current Microbiology 14: 71-77.

33. Heuzenroeder MW, Wong CY, Flower RL (1999) Distribution of two haemolytic toxin genes in clinical and environmental isolates of Aeromonas spp. Correlation with virulence in a suckling mouse model. FEMS Microbiol Lett 174 131-136.

34. Sen K, Rodgers M (2004) Distribution of six virulence factors in Aeromonas species isolated from US drinking water utilities: A PCR identification. J Appl Microbiol 97: 1077-1086.

35. Pollard DR, Johnson WM, Lior H, Tyler SD, Rozee KR (1990) Detection of the aerolysin gene in Aeromonas hydrophila by the polymerase chain reaction. $J$ Clin Microbiol 28: 2477-2481.

36. Li J, Ni XD, Liu YJ, Lu CP (2011) Detection of three virulence genes alt, ahp and aerA in Aeromonas hydrophila and their relationship with actual virulence to zebrafish. J Appl Microbiol 110: 823-830.

37. Costa MM, Drescher G, Maboni F, Maboni F, Weber S, et al. (2010) 
Citation: Emeish WFA, Mohamed HMA, Elkamel AA (2018) Aeromonas Infections in African Sharptooth Catfish. J Aquac Res Development 9: 548. doi: 10.4172/21559546.1000548

Virulence factors, antimicrobial resistance and plasmid content of clinical and environmental Escheirichia coli swine isolates. Arq Bras Med Vet Zootec 62: 30-36.

38. Green MJ, Buckley JT (1990) Site-directed mutagenesis of the hole-forming toxin aerolysin: Studies on the roles of histidines in receptor binding and oligomerization of the monomer. Biochemistry 29: 2177-2180.
39. Sha J, Lu M, Chopra KA (2001) Regulation of the cytotoxic enterotoxin gene in Aeromonas hydrophila: characterization of an iron uptake regulator. Infect Immun 69: 6370-6381.

40. Wong CY, Heuzenroeder MW, Flower RL (1998) Inactivation of two haemolytic toxin genes in Aeromonas hydrophila attenuates virulence in a suckling mouse model. Microbiology 144: 291-298. 